Міршук О. кандидат педагогічних наук,

Національна академія Національної гвардії України

ORCID: 0000-0003-1871-5453

\title{
СИСТЕМА ПРОФЕСІЙНО-ПСИХОЛОГІЧНОЇ ПІДГОТОВКИ В НАЦІОНАЛЬНІЙ ГВАРДІЇ УКРАЇНИ
}

В статті окреслено проблему побудови системи професійно-психологічної підготовки. Проаналізовано сучасні погляди до визначення поняття «професійно-психологічна підготовка». Визначено мету професійно-психологічної підготовки та основні ї̈ завдання. Деталізовано систему професійно-психологічної підготовки в Національній гвардії України, яка складається з n'яти основних складових, а саме: суб'єктів, об 'єктів, форм, методів та засобів.

Ключові слова: психологічне забезпечення; професійно-психологічна підготовка; система професійно-психологічної підготовки; складові системи професійно-психологічної підготовки; психологічне моделювання.

\section{Актуальність дослідження і постановка проблеми.}

Анексія Криму, події на сході України, а саме проведення антитерористичної операції, а згодом операції об'єднаних сил, висувають нові вимоги до особового складу Національної гвардії України (далі - НГУ). Тут важливу роль відіграють не тільки професійна компетентність військовослужбовців, а й їхня психологічна готовність та підготовленість до виконання службовобойових завдань.

Особовий склад НГУ виконує чималу кількість завдань регламентованих нормативно-правовими актами, які пов'язані 3 безліччю стрес-факторів та різноманітних умов які негативно впливають на психоемоційний стан військовослужбовців.

Необхідність психологічної підготовки обумовлена своєрідною специфікою та особливістю виконуваних завдань в процесі професійної діяльності, таких як:

1.Діяльність Національної гвардії України грунтується на принципах верховенства права, забезпечення дотримання прав i свобод людини i громадянина, позапартійності, безперервності, законності, відкритості для демократичного цивільного контролю, прозорості, централізованого єдиноначальності, відповідальності, застосування тортур, катувань та інших жорстких, нелюдських або таких, що принижують гідність, видів поводження та покарання. Вищезазначене вимагає від особового складу наявність як сформованої професійної компетентності, так і високих морально-ділових якостей.

\section{2. Виконання} завдань за призначенням передбачає наявність певних повноважень та обов'язків що визначені законодавчо. Відхилення від виконання обов'язків може призвести до заподіяння істотної моральної шкоди та психічної травми військовослужбовцям. Прийняття рішення в неординарних ситуаціях обумовлене досконалим знанням функціональних обов'язків та нормативно- правових актів, що регламентують діяльність гвардії, відповідальність перед суспільством, психологічною підготовленістю та психічною стійкістю.

3.Наявність вищезазначених повноважень передбачає і високий рівень самостійності та відповідальності військовослужбовців за власні дії та прийняті рішення, що передбачає належний рівень емоційної зрілості, моральності, самоконтролю, знання обов'язків та чіткого усвідомлення персональних дій.

4.Національній гвардії України визначено 20 функцій, які в тій чи іншій мірі насичені різноманітними стресфакторами, а деякі ризиком для життя, наприклад: «участь у здійсненні заходів, пов'язаних 3 припиненням збройних конфліктів...», «участь у спеціальних операціях із знешкодження озброєних злочинців...», «участь у ліквідації наслідків надзвичайних або кризових ситуацій...», «участь у припиненні масових заворушень». Виконання 


\section{Питання психології}

подібного роду функцій передбачає наявність у військовослужбовців високої психічної та стресостійкості, вміння діяти адекватно ситуації, здатність прогнозувати наслідки враховуючи всі наявні фактори, високу емоційну стабільність, критичне мислення тощо.

Для підготовки особового складу до протистояння дії стрес-факторів у різних умовах службово-бойової діяльності необхідно деталізувати систему професійно-психологічної підготовки.

\section{Аналіз останніх досліджень та} публікацій.

Проблему професійно-психологічної підготовки вивчали чимало науковців у сфері психології, зокрема: І.В. Жданова, Г.С. Запорожцева, О.В. Іванова, І.С. Коваль, А. Куліш, С.О. Ларіонов, С.Ю. Лебєдєва, Н.В. Лигун, М.Г. Логачев, О.В. Сахнік, О.М. Скрябін, М.О. Сова, А.І. Черняк, С.О. Чижевський, I.M. Шопіна та ін.

Вищезазначеними авторами зроблено вагомий внесок у розвиток професійнопсихологічної підготовки досліджуючи новітні тренінгові технології, методики, програми, тренінги і тренінгові програми, пропозиції, форми здійснення, специфіку тощо. Розглянуто вітчизняний та іноземний досвіт впровадження та удосконалення професійно-психологічної підготовки. Висвітлено вплив професійнопсихологічної підготовки на формування адаптивних можливостей індивіда тощо.

Зокрема Івановою О.В. та Чижевським C.O., в запропонованому проекті системи професійно-психологічної підготовки військовослужбовців Національної гвардії України на різних етапах виконання службово-бойових завдань в екстремальних (бойових) умовах, було визначено форми професійно-психологічної підготовки, проведено аналіз результатів дослідження наслідків війн на території інших держав а також окремих досліджень психологів Національної гвардії України під час антитерористичної операції, окреслено особливості впровадження у бойову та спеціальну підготовку досвід виконання службово-бойових завдань та вагоме значення діяльності психологів на етапі підготовки гвардійців до них[1].

Але система професійнопсихологічної підготовки повинна складатись не тільки з форм, а й інших складових, що в свою чергу повинні полегшити діяльність керівників у питаннях психологічної підготовленості підлеглих до дій у різних умовах обстановки, саме це спонукало нас на необхідність деталізації системи професійно-психологічної підготовки в Національній гвардії України.

Постановка завдання. Метою статті $\epsilon$ проаналізувати сучасний стан професійно-психологічної підготовки, конкретизувати iï поняття, окреслити складові системи професійнопсихологічної підготовки, визначити елементи що їх формують, конкретизувати завдання, мету.

Методи дослідження. Аналіз i синтез, порівняння, узагальнення та конкретизація.

Виклад основного матеріалу.

Для більш точного уявлення системи професійно-психологічної підготовки необхідно конкретизувати визначення самого поняття - професійнопсихологічна підготовка.

Слід звернути увагу, що професійнопсихологічна підготовка визначалась по різному в залежності від специфіки правоохоронного органу держави - в, Національній поліції України, Державній пенітенціарній службі України, Державній службі України $з$ надзвичайних ситуацій тощо.

Зокрема О.В. Сахнік 3 погляду на психологічну надійність та особисту безпеку персоналу Державної пенітенціарної служби України, зазначає, що головним механізмом боротьби з будьякими негативними психологічними явищами, якими зокрема являються віктимність поведінки та деформація професійно-важливих якостей співробітника пенітенціарної системи, є знання про їх існування та методи самокорекції, сформовані уміння вчасно розпізнавати зародження негативних психоемоційних впливів та протиставляти їм власні антиманіпуляційні механізми [2].

На думку Жданової I.В. та ін. професійно-психологічна підготовка сучасний вид професійної, прикладної, спеціально організованої підготовки працівників правоохоронних органів, що допомагає підготувати їх до подолання 


\section{Питання психології}

психологічних труднощів професійної діяльності i, тим самим, забезпечити успішне розв'язання завдань, що стоять перед ними [3, 10].

3 точки зору Цільмак О.M. та Яковенко C.I. під професійнопсихологічною підготовкою працівників підрозділів громадської безпеки розуміється комплекс взаємопов'язаних навчально-виховних заходів, які спрямовані на формування й розвиток у осіб які навчаються, компетентності та професійно-психологічної готовності до ефективного здійснення правоохоронних функцій [4].

Для адаптації до незвичних умов служби та протидії негативним стрес-факторам відповідними фахівцями Національної гвардії розроблено та впроваджено напрям психологічного забезпечення - професійнопсихологічну підготовку, яка призначена формувати психологічну готовність військовослужбовців, та визначається як комплекс взаємопов'язаних заходів, що здійснюються у загальній системі бойової та спеціальної (професійної) підготовки особового складу НГУ і безпосередньо в процесі службово-бойової діяльності та спрямовані на формування й розвиток психологічних та фізіологічних якостей військовослужбовців для ефективного виконання ними службово-бойових завдань 3 урахуванням їх специфіки та умов [5].

Коваль I.C. наголошує що, для ефективної діяльності, в процесі професійно-психологічної підготовки, майбутній працівник Державної служби України $з$ надзвичайних ситуацій повинен набути фахові якості, такі, як: низький рівень тривожності, емоційну лабільність, готовність до ризику, оскільки їхня професійна діяльність, нерозривно пов'язана із постійним ризиком для життя та здоров'я, великими фізичними та психологічними навантаженнями [6].

Розкриваючи сутність професійнопсихологічної підготовки працівників Державної пенітенціарної служби України Сова М.О. вказує, що слід конкретизувати це поняття як спеціально організований, цілеспрямований процес формування у працівників пенітенціарної служби особистісно-професійних якостей i розвиток психологічних станів, необхідних для успішного, виконання оперативно-службових завдань та досягнення ефективності професійної діяльності [7].

В системі психологічного забезпечення поліцейських, працівників Національної поліції України та курсантів (слухачів) закладів вищої освіти із специфічними умовами навчання, які здійснюють підготовку поліцейських, психологічна підготовка об'єктів системи психологічного забезпечення, визначається як процес формування у працівників поліції, поліцейських закладів вищої освіти, курсантів (слухачів) професійнопсихологічної надійності, стійкості, готовності до різноманітних умов службової діяльності, навичок конструктивної комунікації 3 населенням [8].

Таким чином ми бачимо, що на сьогодні не існує єдиного визначення понятяя «професійно-психологічна підготовка», але 3 вищезазначеного можемо зробити висновок, що це комплекс заходів 3 формування психофізичних здатностей, індивідуальнопсихологічних особливостей та соціальнопсихологічних

якостей військовослужбовців які обумовлюють їхню професійно-психологічну готовність до успішного виконання завдань за призначенням.

Поряд 3 конкретизацією визначення понятя «професійно-психологічна підготовка» необхідно визначити, як саме iii здійснювати, якими формами, методами, засобами, що $\epsilon$ iï змістом, метою та завданнями.

На думку Цільмак О.М. та Яковенко C.I., головною метою професійнопсихологічної підготовки є озброєння осіб знаннями, розвиток i формування професійно значущих якостей, умінь й навичок, що в сукупності детермінують професійно-психологічну готовність працівників міліції до правоохоронної діяльності [4].

Розглянемо деякі погляди Жданової I.В. та iï авторського колективу, щодо мети професійно-психологічної підготовки, а саме:

формування психологічної стійкості, здатності безпомилкового, максимально ефективного вирішення професійних завдань в умовах граничного внутрішнього напруження, уміння 


\section{Питання психології}

володіти собою, не допускаючи зривів у поведінці;

розвиток професійно-важливих психологічних якостей, що є необхідними для успішних дій у складних, напружених та небезпечних обставинах: пильності, мобілізованості, спостережливості, оперативності і точності мислення, інтуїції, сміливості, витривалості, цілеспрямованості, наполегливості, активності, обачності тощо;

розвиток професійно-психологічних умінь та навичок психологічного аналізу обстановки, складання психологічного портрета громадянина, психологічного впливу, психологічної спостережливості, психологічно умілого ведення переговорів [3].

Коваль I.C. зазначає, що для ефективної діяльності, в процесі професійно-психологічної підготовки, майбутній працівник ДСНС повинен набути фахові якості, такі, як: низький рівень тривожності, емоційну лабільність, готовність до ризику, оскільки їхня професійна діяльність, нерозривно пов'язана із постійним ризиком для життя та здоров'я, великими фізичними та психологічними навантаженнями [6].

В положенні про психологічне забезпечення в Національній гвардії України зазначено, що професійнопсихологічна підготовка особового складу здійснюється 3 метою психологічної просвіти особового складу щодо психофізіологічних процесів, які відбуваються в організмі людини в умовах небезпеки, загрози життю, формування навичок регуляції (саморегуляції) психоемоційного стану, порядку отримання (надання) психологічної допомоги (самодопомоги), а також психологічної стійкості до впливу характерних для службової діяльності психотравмуючих факторів формування згуртованості військового колективу додаткового психофізіологічного вивчення якостей військовослужбовців в умовах психічного та фізичного навантаження.

Основні завдання професійнопсихологічної підготовки полягають у: навчанні особового складу методам розпізнавання негативних психологічних станів (розладів), прийомам самоконтролю та саморегуляції власного психоемоційного стану;

формуванні у військовослужбовців психологічної готовності та стійкості до психотравмуючих факторів екстремальних (бойових) умов;

профілактиці колективних форм страху, асоціальної поведінки;

згуртуванні військового колективу підрозділу, військового наряду;

створенні передумов високої бойової активності особового складу;

адаптації військовослужбовців до екстремальних (бойових) умов, їх навчанні основним способам психологічного самозахисту;

підвищенні рівня теоретичних знань, удосконаленні практичних умінь та навичок військовослужбовців 3 надання першої психологічної допомоги (самодопомоги) щодо попередження психотравмування, виявленні ознак психологічних травм;

реадаптації, фізичному та психологічному відновленні особового складу після виконання службово-бойових завдань в екстремальних умовах [5].

На наш погляд вищезазначені мета i завдання професійно-психологічної підготовки в Національній гвардії України, $є$ найбільш оптимальними 3 точки зору комплексного підходу до формування даного виду готовності військовослужбовців, яка охоплює діапазон від теоретичної підготовки до практики в ключових моментах, що стосуються адаптації, попередження, профілактики, розпізнавання негативних психологічних станів військовослужбовців, як в звичайних умовах так $\mathrm{i}$ в умовах насичених психотравмуючими факторами.

Розглядаючи погляди на систему професійно-психологічної підготовки в цілому, можна припустити, що науковцями які досліджують цю проблематику недостатньо приділяється увага самій структурі та складовим даної системи.

Під системою професійнопсихологічної підготовки працівників системи МВС України слід розуміти сукупну узгоджену діяльність спеціальність підрозділів психологічного 


\section{Питання психології}

забезпечення, науково-дослідних установ, навчальних закладів, практичних органів MBC України, що спрямована на підвищення ефективності їх оперативнослужбової діяльності та боєздатності шляхом цілеспрямованого використання науково обгрунтованих форм, методів i засобів професійної психології, вважає Жданова І.В. та іiі авторський колектив [3].

Система професійно-психологічної підготовки повинна містити в собі суб'єкти, об'єкти, форми, методи та засоби за допомогою яких діяльність щодо формування готовності у військовослужбовців до виконання завдань за призначенням може бути здійснена в повному обсязі.

Суб' єктами

професійнопсихологічної підготовки є: психологи, офіцери по роботі з особовим складом, командири (начальники) усіх рівнів, керівники занять з бойової та спеціальної підготовки, начальники варт та військових нарядів, інструктори, науковопедагогічний склад вищих військових начальних закладів, медичні працівники тощо.

Головне завдання суб' єктів полягає у планомірному застосуванні форм, методів i засобів професійно-психологічної підготовки під час занять з бойової та спеціальної підготовки, а також у повсякденній діяльності для формування й розвитку психологічних та фізіологічних якостей військовослужбовців для ефективного виконання ними завдань за призначенням.

Об'єктами професійно-психологічної підготовки є наступні категорії:

офіцери;

військовослужбовці військової

служби за контрактом;

військовослужбовці

строкової

служби;

курсанти вищих військових

навчальних закладів;

військовослужбовці і резервісти, які призвані до з'єднань, військових частин, підрозділів НГУ на навчальні (перевірочні) та спеціальні збори, призвані за мобілізацією;

варти та військові наряди;

особи цивільного персоналу

(працівники, службовці), які залучаються до виконання завдань служби в екстремальних (бойових) умовах, тощо.

На об'єкти професійно-психологічної підготовки спрямований вплив всіх інших складових даної системи. Як видно 3 вищезазначеного до цієї складової системи відносяться всі категорії військовослужбовців та працівників які залучаються до виконання завдань служби 3 підвищеним ризиком впливу стресфакторів.

Згідно 3 Положенням про психологічне забезпечення в Національній гвардії України, до основних форм професійно-психологічної підготовки відносяться практичні тренінгові заняття, психологічні лекторії, психологічне моделювання, начальні заняття 3 бойової та спеціально підготовки, психологічне інформування психологічний тренінг тощо [5].

3 методологічної точки зору всі вищезазначені форми можна віднести до системи професійно-психологічної підготовки, окрім психологічного моделювання, воно на нашу думку, в повній мірі відноситься до методів, а не до форм.

За допомогою форм реалізується мета професійно-психологічної підготовки i більшість із них можна спланувати та реалізувати у встановленому порядку. Що ж стосується психологічного моделювання, то його потрібно застосовувати під час реалізації форм професійно-психологічної підготовки, і це $€$ об'єктом наших перспективних досліджень.

Різноманітність методів, що застосовуються під час професійнопсихологічної підготовки обумовлена широким спектром завдань самої професійно-психологічної підготовки. Методи професійно-психологічної підготовки варто поділити на вербальні та практичні.

До вербальних методів відносяться усний виклад матеріалу, інструктаж, переконання, навіювання, накази, поради, консультації тощо. Вони призначені викликати у психіці бажані зміни і на їх основі сформувати стійкі позитивні звички.

Практичні методи включають в себе: різноманітні вправи, тренінги (когнітивні, 


\section{Питання психології}

комунікативні, рольові), ігри, психологічне моделювання (моделювання різноманітних ситуацій), показ тощо. Призначення цих методів полягає в посиленні та закріпленні у особового складу ефекту впливу на когнітивну та поведінкову сфери особистості і готовності до практичних видів діяльності.

Засоби професійно-психологічної підготовки це сукупність використовуваних під час реалізації форм та методів - різноманіття об'єктів, прийомів та інших впливів на військовослужбовців та працівників, 3 метою досягнення необхідного ефекту на шляху до формування їхньої готовності до дій в різних умовах.

Говорячи про засоби професійнопсихологічної підготовки можна підкреслити що Національна гвардія України $\epsilon$ провідним військовим формуванням яке успішно використовує широкий спектр засобів, в який входять: психотренінгові комплекси, психологічні смуги, тренінгові містечка командного згуртування, місця проведення практичних занять, навчальні транспортні засоби, макети споруд та транспортних засобів, різноманітні тренажери сучасної бойової техніки та зброї, імітаційні засоби, наочні засоби, технічні засоби тощо.

Бойові навчання $\epsilon$ базою для будування ефективного підрозділу, але реальні події службово-бойових завдань можуть доволі сильно відрізнятися від сценаріїв навчань. Саме тому необхідна система забезпечення службово-бойової готовності військовослужбовців у подібних ситуаціях та після них - від командира до рядового. Базою психологічної готовності командира $\epsilon$ гнучкість та вміння адаптуватись. Завдання військового психолога у системі професійної підготовки перед виконання завдань служби в екстремальних (бойових) умова спрямовані на формування внутрішньої готовності військовослужбовців до впливу бойових стрес-факторів.

Кожен

військовослужбовець у свою чергу зобов'язаний усвідомити, що будь-яка реакція його організму в екстремальних (бойових) умовах - це нормальна реакція на ненормальні обставини, також він повинен володіти навиками першої психологічної допомоги (самодопомоги), саморегуляції психоемоційного стану [1].

3 вищезазначеного можна винести, що для готовності перебування в екстремальних ситуаціях, та швидко адаптуватись до умов насичених бойовими стрес-факторами необхідно створювати відповідні умови під час навчання, шляхом застосування певних засобів та прийомів.

Як позитивне, варто відмітити застосування психологічної смуги, під час професійно-психологічної підготовки Психологічна смуга імітації екстремальних (бойових) умов службовобойової діяльності підрозділів НГУ - це спеціально обладнані ділянки навчального центру, де моделюються екстремальні (бойові) умови (ситуаціі) службовобойової діяльності підрозділів НГУ 3 урахуванням завдань за призначенням, для проходження яких необхідно подолання навантажень психологічного і фізичного характеру, 3 оперативним управлінням психологічними процесами особистості [9]. Данна психологічна смуга має подвійну мету: по-перше - розвиток фізичних якостей військовослужбовців, як необхідної складової життєдіяльності військовослужбовців, по-друге формування психічної стійкості, через застосування елементів психологічного моделювання, які створюють реалістичну картину бою та формують досвід перебування під тиском психотравмуючих факторів.

Також хочемо зазначити про запровадження та передовий досвід використання тренінгових містечок командного згуртування які використовуються для тренінгових програм, що призначені для організації та проведення занять 3 професійнопсихологічної підготовки особового складу на навчальних зборах поповнення, у новосформованих підрозділах НГУ за напрямком згуртування колективу, а також вивчення його соціальної структури [10]. Вправи на тренажерах тренінгового містечка командного згуртування здійснюють ефективний вплив на посилення командної роботи, виявлення лідерів та референтних осіб, підвищують рівень довіри в підрозділах про що 


\section{Питання психології}

свідчать аналіз проведених соціометричних досліджень та вивчення соціально-психологічного клімату.

На підставі викладеного вище слід зазначити, що система професійнопсихологічної підготовки НГУ, має практичну значимість для формування у військовослужбовців психологічної підготовленості до виконання завдань за призначенням, та на наш погляд повинна мати наступний вигляд (див. Рис. 1.)

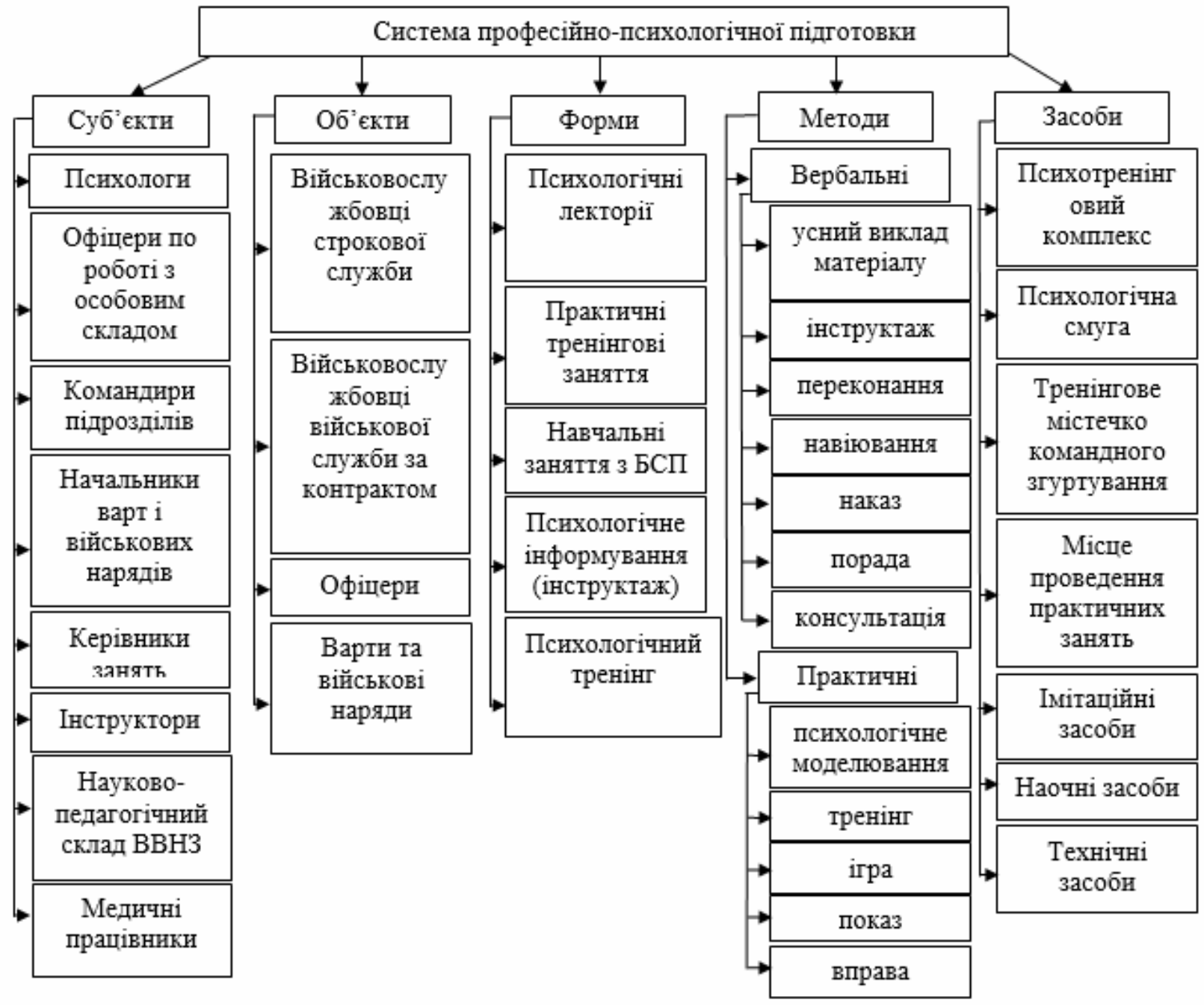

Рис.1 Система професійно-психологічної підготовки НГУ

Висновки та перспективи індивідуально-психологічних

подальших досліджень.

Отже роблячи висновки можемо стверджувати, що сукупність всього різноманіття поглядів на проблематику нашого дослідження вказує на невизначеність усталених стандартів. Окреслена нами система професійнопсихологічної підготовки не $\epsilon$ принциповою, але в вихідній обгрунтованій теорії, яка визначає іiі концептуально-методологічний підхід до постановки і вирішення нашого завдання, можемо стверджувати, що в Національній гвардії України професійно-психологічна підготовка це комплекс заходів 3 формування психофізичних здатностей, особливостей та соціально-психологічних якостей військовослужбовців які обумовлюють їхню професійнопсихологічну готовність до успішного виконання завдань за призначенням. Данна система повинна складатись 3 п'яти основних складових, а саме: суб'єктів, об'єктів, форм, методів та засобів, які взаємозалежні та необхідні для успішної реалізації завдань професійнопсихологічної підготовки в діяльності Національної гвардії України. Кожна із складових даної системи розділена на різноманіття категорій які іiі втілюють в життя. Дані категорії виступають в ролі реалізаторів складових

системи 


\section{Питання психології}

професійно-психологічної підготовки

НГУ.

До перспективних напрямів

досліджень можна віднести окреслення етапів професійно-психологічної

підготовки, співвідношення завдань професійно-психологічної підготовки 3 формами якими вони реалізуються. Також необхідно приділити значну увагу застосуванню методу психологічного моделювання в Національній гвардії України.

\section{Список використаних джерел}

1. Іванова О.В.Професійно-психологічна підготовка військовослужбовців Національної гвардії України / О. В. Іванова, С. О. Чижевський // Актуальні проблеми соціології, психології, педагогіки. - 2015. - № 4. - С. 59-65.

2. Сахнік О. В. Професійно-психологічна підготовка персоналу державної пенітенціарної служби України як засіб забезпечення його особистої безпеки та надійності / О. В. Сахнік // Юридична психологія та педагогіка. - 2014. - № 1. - С. 106-114.

3. Професійно-психологічна підготовка працівників слідчих підрозділів : навч. посіб. / [І.В. Жданова, П.В. Макаренко, Н.Е. Мілорадова та ін.] ; за заг. ред. І.В. Жданової ; МВС України, Харків. нац. ун-т внутр. справ. - Харків : ХНУВС, 2014. - 516 с.

4. Цільмак О.М., Яковенко С.І. Професійно-психологічна підготовка працівників підрозділів громадської безпеки. [ Текст ] : підручник. / О.М. Цільмак, С.І. Яковенко. - Одеса: ОДУВС, 2012. - 140 с.

5. Про затвердження Положення про психологічне забезпечення в Національній гвардії України : наказ МВС України від 08.12.2016 р. № 1285. - К., 2016

6. Коваль І.С. Професійно-психологічна підготовка майбутніх рятувальників ДСНС України / I. С. Коваль // Науковий часопис Національного педагогічного університету імені М. П. Драгоманова. Серія 19 : Корекційна педагогіка та спеціальна психологія. - 2015. - Вип. 29. - С. 178-183.

7. Сова М. О. Професійно-психологічна підготовка працівників пенітенціарної служби до саморегуляції в екстремальних ситуаціях оперативно-службової діяльності / М. О. Сова // Науковий вісник Інституту кримінально-виконавчої служби. - 2014. - № 2. - С. 136-148.

8. Про затвердження Порядку організації системи психологічного забезпечення поліцейських, працівників Національної поліції України та курсантів (слухачів) закладів вищої освіти із специфічними умовами навчання, які здійснюють підготовку поліцейських : наказ МВС України від 06.02.2019 р. № 88. - К., 2019

9. Про затвердження методичних рекомендацій про засади побудови та порядок експлуатації психологічної смуги імітації екстремальних (бойових) умов службово-бойової діяльності підрозділів Національної гвардії України : наказ Командувача НГУ від 04.04.2016 p. № 188. - К., 2016

10. Програма тренінгу створення команди / С.О. Чижевський, І.І. Приходько, О.О. Колесніченко та ін. / Під заг. ред. генерал-майора Я.Б. Сподара. - К.: Друкарня ІВЦ НГУ, 2016 - 28 с.

\section{References}

1. Ivanova, O.V., \& Chizhevskii, S.O. (2015). Profesiino-psykholohichna pidhotovka viiskovosluzhbovtsiv Natsionalnoi hvardii Ukrainy [Professional-psychological training of servicemen of the National Guard of Ukraine]. Actual problems of sociology, psychology, pedagogy, 4, 59-65 (in Ukrainian).

2. Sahnik, O.V. (2014). Profesiino-psykholohichna pidhotovka personalu derzhavnoi penitentsiarnoi sluzhby Ukrainy yak zasib zabezpechennia yoho osobystoi bezpeky ta nadiinosti [Professional and psychological training of the staff of the State Penitentiary Service of Ukraine as a means of ensuring its personal safety and reliability]. Legal psychology and pedagogy, 1, 106-114 (in Ukrainian).

3.Zdanova, I.V., Makarenko, P.V., \& Miloradova, N.E. et al. (2014). Profesiino-psykholohichna pidhotovka pratsivnykiv slidchykh pidrozdiliv [Professional and psychological training of employees of investigative units: manual]. KHARKIV: KhNUVS (in Ukrainian).

4. Tsilmak, O.M, \& Yakovenko S.I. (2012). Profesiino-psykholohichna pidhotovka pratsivnykiv pidrozdiliv hromadskoi bezpeky [Professional and psychological training of employees of public order protection]. ODESA: ODUVS (in Ukrainian).

5. Pro zatverdzhennia Polozhennia pro psykholohichne zabezpechennia $\mathrm{v}$ Natsionalnii hvardii Ukrainy [Approval of the Regulation on psychological support in the National Guard of Ukraine] № 1285. (2016, December 08). Order of the Minister of the Interior, 79 (in Ukrainian). 


\section{Питання психології}

6. Koval, I.S. (2015). Profesiino-psykholohichna pidhotovka maibutnikh riatuvalnykiv DSNS Ukrainy [Professional and psychological training of future rescuers of the SES of Ukraine]. Scientific journal of MP Dragomanov National Pedagogical University. Correctional Pedagogy and Special Psychology, 19 (29), 178-183 (in Ukrainian).

7. Sova, M.O. (2014). Profesiino-psykholohichna pidhotovka pratsivnykiv penitentsiarnoi sluzhby do samorehuliatsii $\mathrm{v}$ ekstremalnykh sytuatsiiakh operatyvno-sluzhbovoi diialnosti [Professionalpsychological training of prison staff for self-regulation in extreme situations of operational and service activities]. Scientific Bulletin of the Institute of Criminal Enforcement Service, 2, 136-148 (in Ukrainian).

8. Pro zatverdzhennia Poriadku orhanizatsii systemy psykholohichnoho zabezpechennia politseiskykh, pratsivnykiv Natsionalnoi politsii Ukrainy ta kursantiv (slukhachiv) zakladiv vyshchoi osvity iz spetsyfichnymy umovamy navchannia, yaki zdiisniuiut pidhotovku politseiskykh [Approval of the Order of organization of the system of psychological support for police officers, employees of the National Police of Ukraine and cadets (students) of higher education institutions with specific training conditions that provide police training] № 88. (2019, February 06). Order of the Minister of the Interior (in Ukrainian).

9. Pro zatverdzhennia metodychnykh rekomendatsii pro zasady pobudovy ta poriadok ekspluatatsii psykholohichnoi smuhy imitatsii ekstremalnykh (boiovykh) umov sluzhbovo-boiovoi diialnosti pidrozdiliv Natsionalnoi hvardii Ukrainy [Approval of methodological recommendations on the principles of construction and operation of the psychological strip of imitation of extreme (combat) conditions of service and combat activity of units of the National Guard of Ukraine] № 188. (2016, Apryl 04). Order of the Commander of the National Guard of Ukraine (in Ukrainian).

10. Chizevskii, S.O., Prykhodko, I.I. \& Kolesnichenko, O.S. et al. (2016). Prohrama treninhu stvorennia komandy [Team building training program]. KYIV: IVC NGU (in Ukrainian).

\section{Резюме \\ Миршук А. кандидат педагогических наук, Начиональная академия Национальной гвардии Украинь СИСТЕМА ПРОФЕССИОНАЛЬНО-ПСИХОЛОГИЧЕСКОЙ ПОДГОТОВКИ В НАЦИОНАЛЬНОЙ ГВАРДИИ УКРАИНЫ}

В статье обозначены проблемы построения системы профессионально-психологической подготовки. Проанализированы современные взгляды к определению понятия «профессиональнопсихологическая подготовка». Определены цели профессионально-психологической подготовки и основные ее задачи. Детализировано систему профессионально-психологической подготовки в Национальной гвардии Украины, которая состоит из пяти основных составляющих, а именно: субъектов, объектов, форм, методов и средств.

Ключевые слова: Психологическое обеспечение; профессионально-психологическая подготовка; система профессионально-психологической подготовки; составляющие системы профессионально-психологической подготовки; психологическое моделирование.

\section{Summary}

Mirshuk O. Candidate of Pedagogical Sciences,

National Academy of the National Guard of Ukraine

\section{PROFESSIONAL-PSYCHOLOGICAL TRAINING SYSTEM IN THE NATIONAL GUARD} OF UKRAINE

Introduction The article examines the specificity and peculiarity of the tasks performed in the process of professional activity, which stipulates the need for professional and psychological training in the National Guard of Ukraine.

Purpose The purpose of the article is to analyze the current state of professional-psychological training, to specify its concepts, to describe the components of the system of professional-psychological training, to identify the elements that form them, to specify the tasks and purpose.

Methods Analysis and synthesis, comparison, generalization and concretization.

Originality The views of different authors and their contribution to the development of professional and psychological training in Guard-related structures, in particular the State Emergency Service of Ukraine, the National Police of Ukraine and other structures such as the State Penitentiary Service of Ukraine. Theoretical analysis has been made and modern views have been analyzed to define the concept of "professional-psychological training" and the optimal variant of this concept has been proposed. The purpose of psychological training and its main tasks at the present stage of the development of the troops 


\section{Питання психології}

have been specified and determined. The tasks of subjects of psychological and professional training have been determined. The system of professional and psychological training in the National Guard of Ukraine is outlined, which consists of five main components, namely: subjects, objects, forms, methods and means. Various categories of each of the components of this system are revealed by which it will be possible to realize the main purpose of professional-psychological training - formation of psychophysical abilities, individual-psychological characteristics and social-psychological qualities of servicemen that determine their professional-psychological readiness for successful fulfillment of their commitment to successful completion. For convenience, the above components and categories of the system have been illustrated as a diagram. Positive experience of the National Guard of Ukraine concerning the use of a wide range of various means of vocational and psychological training during daily activities has been determined. Emphasis is placed on the use of training camps as a necessary element of professional and psychological training. Conclusions are made and directions for further research in the field of psychological training are outlined, with the prospect of improving this area of psychological support in the National Guard of Ukraine.

Conclusion The totality of the diversity of views on the subject of our study indicates the uncertainty of the affirmed standards. Our system of professional-psychological training is not fundamental, but according to an analysis carried out in the article, we can state that in the National Guard of Ukraine professional-psychological training is a complex of measures for the formation of psychophysical abilities, individual-psychological characteristics and socio-psychological qualities of military personnel that determine their professional and psychological readiness for successful completion of tasks on purpose. This system should consist of five main components: subjects, objects, forms, methods and means, which are interdependent and necessary for the successful completion of the tasks of professional-psychological training in the activities of the National Guard of Ukraine. Each of the components is divided into a variety of categories that realize the system. These categories act as implementers of the components of the system of professional and psychological training of the NGU. Perspective directions of research include delineation of the stages of professional-psychological training, correlation of tasks of professional-psychological training with the forms in which they are implemented. Consideration should also be given to the application of the method of psychological modeling in the National Guard of Ukraine.

Keywords: Psychological support; professional-psychological training; system of professionalpsychological training; components of the system of professional-psychological training; psychological modeling. 